Gut, 1963, 4, 322

\title{
The composition of ileostomy fluid
}

\author{
T. KANAGHINIS, M. LUBRAN, AND N. F. COGHILL \\ From the West Middlesex Hospital, Isleworth, Middlesex
}

EDITORIAL SYNOPSIS The paper presents data on the sodium, potassium, and water content of ileostomy dejecta from 12 patients with new ileostomies and six patients with established ones. The effects of administration of electrolytes and codeine on these parameters are described. The literature on the chemistry of ileostomy is critically reviewed.

Much is now known about the metabolism of sodium and potassium and the effects on the body when these electrolytes are deficient. Their loss through the skin, kidney, and bowels has been well studied, but less is known about their excretion through artificially created stomata of the bowel. The earliest reliable studies of small intestinal contents in the human were reported by Miller and Abbott (1934), who obtained specimens of jejunal and ileal contents from fasting humans by means of a specially devised tube.

These investigations were extended by Karr and Abbott (1935), who studied the effect of orally administered hydrochloric acid, sodium bicarbonate, and water on the tonicity and anion composition of ileal and jejunal contents. They did not measure the sodium or potassium concentrations of these fluids. Welch, Masson, and Wakefield (1937) reported one patient with an overactive ileostomy, from which $1.33 \mathrm{~g}$. of sodium was lost each day. Welch, Adams, and Wakefield (1937) deduced that the fluid delivered to the colon had a total cation concentration of 150 to $170 \mathrm{mEq}$. per litre, about 120 to $130 \mathrm{mEq}$. per litre being sodium. The composition of this fluid was comparable to that obtained from a patient with an ileal stoma. Dick, Maddock, and Coller (1937) found the sodium concentration of enterostomy drainage fluid in two patients to be 106 and $95 \mathrm{mEq}$. per litre respectively.

The first systematic measurements of sodium and potassium in ileostomy fluid were made by Lockwood and Randall (1949) and later extended by Randall (1952) (Table I). Randall pointed out that if treatment were confined to restoring water loss, sodium deficiency could easily occur in these patients through loss of fluid in the ileostomy dejecta. When ileostomy dejecta volumes were large, potassium deficiency could also occur. He recommended that, in most cases, loss of fluid through the ileostomy should be replaced by an equivalent volume of isotonic saline, except when large volumes of dejecta were lost. In this case, they should be analysed and a quantitative replacement of sodium, potassium, and water made.

Electrolyte concentrations of ileostomy dejecta have also been reported by Maddock (1949), Lans, Stein, and Meyer (1952), MacFadyen, Akre, Duncan, Flesch, and Mauser (1954), and Coghill, Lubran, McAllen, Edwards, and Richenberg (1956) (Table I). The last authors also investigated sodium loss in ileostomy dejecta using ${ }^{24} \mathrm{Na}$ and reported investigations in one patient with acute ileitis. The data on this patient are reported in more detail in the present paper (case 6). Crawford and Brooke (1957) and Brooke (1958) presented data on seven patients with ileostomies (Table I). They suggested that the amount of sodium required for replacement therapy during the first few post-operative days could be calculated by a rule of thumb procedure, in which $300 \mathrm{mEq}$. of sodium chloride was given for each litre of ileostomy fluid lost. These authors also thought that, provided potassium deficiency were corrected before operation, potassium supplements were unnecessary after operation, unless enteritis developed. It was pointed out by Abbott, Levey, and Krieger (1957) and by Lubran, Coghill, and McAllen (1957) that the sodium concentrations found by these authors in ileostomy dejecta were much higher than those found by other workers. It was subsequently suggested by Crawford and Brooke (1958) that their high sodium figures were due to oral administration of enteric-coated salt tablets, which might have escaped complete digestion.

Further data have been published by Fowler, Cooke, Brooke, and Cox (1959), Smiddy, Gregory, Smith, and Goligher (1960), and Kramer, Kearney, and Ingelfinger (1962) (Table I). Fowler et al. (1959) noted a greatly increased loss of potassium in the ileostomy dejecta of a patient with acute ileitis. Smiddy et al. (1960) reported increased loss of sodium and potassium in this condition. 
TABLE I

SODIUM AND POTASSIUM COMPOSITION OF DEJECTA FROM NEW AND ESTABLISHED ILEOSTOMIES REPORTED IN THE LITERATURE

\begin{tabular}{|c|c|c|c|c|c|c|c|c|c|c|c|}
\hline \multirow[t]{3}{*}{ Author } & \multicolumn{2}{|c|}{ No. of Patients } & \multirow{3}{*}{$\begin{array}{l}\text { No. of } \\
\text { Specimens }\end{array}$} & \multicolumn{4}{|c|}{ Concentration ( $m E q$. per litre) } & \multicolumn{4}{|c|}{ Daily Loss (mEq.) } \\
\hline & \multirow[t]{2}{*}{ New } & \multirow{2}{*}{$\begin{array}{l}\text { Esta- } \\
\text { blished }\end{array}$} & & \multicolumn{2}{|l|}{ New } & \multicolumn{2}{|c|}{ Established } & \multicolumn{2}{|l|}{ New } & \multicolumn{2}{|c|}{ Established } \\
\hline & & & & $\mathrm{Na}$ & $\boldsymbol{K}$ & $\mathrm{Na}$ & $\boldsymbol{K}$ & $N a$ & $\boldsymbol{K}$ & $N a$ & $\boldsymbol{K}$ \\
\hline \multicolumn{12}{|l|}{ Lockwood and Randall } \\
\hline (1949) & 1 & 1 & - & 130 & 11 & 46 & 3 & & & & \\
\hline Maddock (1949) & 1 & & - & 155 & & & & & & & \\
\hline Randall $^{1}$ (1952) & 7 & . & 25 & 129 & 16 & & & & & & \\
\hline Lans, Stein, and Meyer & & & & & & & & & & & \\
\hline $\begin{array}{l}\text { (1952) } \\
\text { MacFadyen, Akre, Duncan. }\end{array}$ & 1 & & 12 & 132 & $6 \cdot 2$ & & & & & & \\
\hline $\begin{array}{l}\text { Flesch, and Mauser }{ }^{2} \text { (1954) } \\
\text { Eoghill, Lubran, McAllen, } \\
\text { Edwards, and Richenberg }{ }^{1}\end{array}$ & & - & - & $120-200$ & $15-60$ & & & & & & \\
\hline (1956) & 3 & 1 & 62 & 150 & 7 & 120 & & & & & \\
\hline Crawford and Brooke (1957) & 4 & $3 \cdots$ & About 125 & $200-400$ & $10-20$ & 150 & $10-20$ & & & & \\
\hline $\begin{array}{l}\text { Fowler, Cooke, Brooke, } \\
\text { and Cox' (1959) } \\
\text { Smiddy, Gregory, Smith, }\end{array}$ & 10 & 5 & - & $115-145$ & $10-22$ & $90-135$ & $6-13$ & 70 & 20 & $20-70$ & $\begin{array}{l}\text { Less } \\
\text { than } 10\end{array}$ \\
\hline $\begin{array}{l}\text { and Goligher (1960) } \\
\text { Kramer, Kearney, and }\end{array}$ & 16 & 2 & $216^{2}$ & 120 & & 120 & & $40-60$ & $1-12$ & $30-60$ & $3-4$ \\
\hline Ingelfinger (1962) & & 7 & 71 & & & $107 \cdot 8$ & $7 \cdot 2$ & & & $60 \cdot 3$ & $3 \cdot 6$ \\
\hline Present series ${ }^{1}$ (1962) & 10 & 8 & 295 & $116 \cdot 5$ & $22 \cdot 3$ & $112 \cdot 5$ & $12 \cdot 0$ & 36 & $6 \cdot 1$ & 53 & $5 \cdot 5$ \\
\hline
\end{tabular}

${ }^{1}$ Concentration in $\mathrm{mEq}$. per $\mathrm{kg}$. ileostomy dejecta

${ }^{2}$ Concentration deduced from data

TABLE II

CLINICAL DATA AND OPERATIONS PERFORMED ON ALL PATIENTS

\begin{tabular}{|c|c|c|c|c|c|c|c|c|}
\hline $\begin{array}{l}\text { Case } \\
\text { No. }\end{array}$ & Diagnosis & Ileostomy & $\begin{array}{l}\text { Operations } \\
\text { Performed before } \\
\text { Study }\end{array}$ & $\begin{array}{l}\text { Interval } \\
\text { between Onset } \\
\text { of Disease } \\
\text { and Operation } \\
(y r .)\end{array}$ & $\begin{array}{l}\text { Interval } \\
\text { between } \\
\text { Creation of } \\
\text { Ileostomy and } \\
\text { Start of Study }\end{array}$ & $\begin{array}{l}\text { Interval } \\
\text { between Last } \\
\text { Operation and } \\
\text { Start of } \\
\text { Study }\end{array}$ & Complications & $\begin{array}{l}\text { No. of } \\
\text { Days } \\
\text { Studied }\end{array}$ \\
\hline $\begin{array}{l}1 \\
2 \\
3 \\
4(18) \\
5\end{array}$ & $\begin{array}{l}\text { U.C. } \\
\text { U.C. } \\
\text { U.C. } \\
\text { U.C. } \\
\text { U.C. }\end{array}$ & $\begin{array}{l}\text { New } \\
\text { New } \\
\text { New } \\
\text { New } \\
\text { New }\end{array}$ & $\begin{array}{l}\text { S.C. + ileo. } \\
\text { S.C. + ileo. } \\
\text { S.C. + ileo. } \\
\text { S.C. + ileo. } \\
\text { S.C. + ileo. } \\
\text { Ex. rect. and sig. }\end{array}$ & $\begin{array}{l}17 \\
1 \\
6 \mathrm{wk} . \\
13 \\
4 \mathrm{mth} . \\
4 \frac{1}{2} \mathrm{mth} .\end{array}$ & $\begin{array}{l}3 \text { days } \\
3 \text { days } \\
8 \text { days } \\
3 \text { days } \\
68 \text { days }\end{array}$ & $\begin{array}{l}3 \text { days } \\
3 \text { days } \\
8 \text { days } \\
3 \text { days } \\
46 \text { days }\end{array}$ & $\begin{array}{l}\text { None } \\
\text { Ileitis } \\
\text { None } \\
\text { None } \\
\text { None }\end{array}$ & $\begin{array}{l}13 \\
18 \\
13 \\
13 \\
12\end{array}$ \\
\hline $\begin{array}{l}6 \\
7 \\
8 \\
9\end{array}$ & $\begin{array}{l}\text { U.C. } \\
\text { U.C. } \\
\text { U.C. } \\
\text { Crohn's disease of } \\
\text { colon }\end{array}$ & $\begin{array}{l}\text { New } \\
\text { New (colostomy) } \\
\text { New } \\
\text { New }\end{array}$ & $\begin{array}{l}\text { S.C. + ileo. } \\
\text { L. hc. + T.C. } \\
\text { S.C. + ileo. } \\
\text { L. hc. + T.C. } \\
\text { R. hc. + ileo+ } \\
\text { ex. rect. and sig. }\end{array}$ & $\begin{array}{l}2 \frac{1}{2} \\
12 \\
3 \\
1 \frac{8}{4} \\
1 \mathrm{H}\end{array}$ & $\begin{array}{l}1 \text { day } \\
6 \text { days } \\
1 \text { day } \\
8 \text { days }\end{array}$ & $\begin{array}{l}1 \text { day } \\
6 \text { days } \\
1 \text { day } \\
8 \text { days }\end{array}$ & $\begin{array}{l}\text { Ileitis } \\
\text { None } \\
\text { None } \\
\text { None }\end{array}$ & $\begin{array}{l}42 \\
18 \\
28 \\
19\end{array}$ \\
\hline $\begin{array}{l}10 \\
11 \\
12\end{array}$ & $\begin{array}{l}\text { U.C. } \\
\text { U.C. } \\
\text { Familial polyposis }\end{array}$ & $\begin{array}{l}\text { New } \\
\text { New } \\
\text { Established }\end{array}$ & $\begin{array}{l}\text { S.C. + ileo. } \\
\text { S.C. + ileo. } \\
\text { Staged total }\end{array}$ & $\begin{array}{l}3 \\
5\end{array}$ & $\begin{array}{l}9 \text { days } \\
2 \text { days }\end{array}$ & $\begin{array}{l}9 \text { days } \\
2 \text { days }\end{array}$ & $\begin{array}{l}\text { Obstruction } \\
\text { None }\end{array}$ & $\begin{array}{r}22 \\
5\end{array}$ \\
\hline 13 & $\begin{array}{l}\text { of colon } \\
\text { U.C. }\end{array}$ & Established & $\begin{array}{l}\text { colectomy +ileo. } \\
\text { S.C. + ileo. } \\
\text { Ex. rect. and sig. }\end{array}$ & $\begin{array}{l}\overline{23} \\
238\end{array}$ & $\begin{array}{l}6 \frac{1}{2} \text { years } \\
9 \text { months }\end{array}$ & $\begin{array}{l}6 \frac{1}{2} \text { years } \\
9 \text { days before } \\
\text { last operation }\end{array}$ & $\begin{array}{l}\text { None } \\
\text { None }\end{array}$ & $\begin{array}{l}18 \\
20\end{array}$ \\
\hline 14 & U.C. & Established & $\begin{array}{l}\text { S.C. + ileo. } \\
\text { Ex. rect. and sig. }\end{array}$ & 5 & 6 months & 3 days & None & 20 \\
\hline 15 & U.C. & Established & $\begin{array}{l}\text { Ileo. } \\
\text { S.C. } \\
\text { Ex. rect. and sig. }\end{array}$ & $\begin{array}{r}7 \\
14 \\
22\end{array}$ & 15 years & 1 day & None & 11 \\
\hline 16 & U.C. & Established & $\begin{array}{l}\text { S.C. + ileo. } \\
\text { Ex. rect. and sig. }\end{array}$ & $\begin{array}{l}13 \\
14\end{array}$ & 2 years & 1 year & Obstruction & 5 \\
\hline 17 & $\begin{array}{l}\text { U.C. } \\
\text { D.U. } \\
\text { P.G. } \\
\text { Steat. }\end{array}$ & Established & $\begin{array}{l}\text { R. hc. } \\
\text { Ileo. } \\
\text { Refashion ileo. } \\
\text { L. hc. } \\
\text { Refashion ileo. } \\
\text { P.G. }\end{array}$ & $\begin{array}{l}3 \\
5 \\
5 \frac{1}{2} \\
6 \\
7 \\
9\end{array}$ & 7 years & 3 years & $\begin{array}{l}\text { Ileal diarrhoea, } \\
\text { steatorrhoea } \\
\text { (after partial } \\
\text { gastrectomy) }\end{array}$ & 11 \\
\hline $18(4)$ & U.C. & Established & $\begin{array}{l}\text { See } 4 \\
\text { Ex. rect. and sig. }\end{array}$ & $13 \frac{2}{8}$ & 8 months & 4 days & None & 22 \\
\hline $\begin{array}{ll}\text { D.U. I } \\
\text { Ex. } \\
\text { hc. }\end{array}$ & $\begin{array}{l}\text { Duodenal ulcer } \\
\text { Excision } \\
\text { Hemicolectomy }\end{array}$ & $\begin{array}{l}\text { ileo. Ileostomy } \\
\text { L. Left } \\
\text { P.G. Partial gastrec }\end{array}$ & $\begin{array}{ll}\text { R. } & \mathbf{R} \\
\text { rect. } & \mathbf{R} \\
\text { sig. } & \mathbf{S i}\end{array}$ & $\begin{array}{l}\text { ht } \\
\text { tum } \\
\text { noid colon }\end{array}$ & $\begin{array}{l}\text { steat. Steatorrl } \\
\text { S.C. Subtotal }\end{array}$ & $\begin{array}{l}\text { hoea } \\
\text { colectomy }\end{array}$ & $\begin{array}{l}\text { C. Transverse } \\
\text { C. Ulcerative c }\end{array}$ & $\begin{array}{l}\text { lostomy } \\
\text { litis }\end{array}$ \\
\hline
\end{tabular}


It will be seen from Table I that satisfactory data concerning the sodium and potassium content of ileostomy dejecta have previously been reported for only 62 patients, of whom 19 had established ileostomies. In this paper, we present the results of chemical investigations of the ileostomy dejecta of 18 patients and, for comparison, dejecta from one patient with a transverse colostomy. The main problems studied have been the losses of water, sodium, and potassium in the dejecta, the changes in their composition as the ileostomy becomes established, and the effect of fluids, salts, and drugs on the sodium, potassium, and water content of ileostomy fluid.

\section{CLINICAL MATERIAL}

There were 16 patients with ulcerative colitis of whom 15 had an ileostomy and one a transverse colostomy (case 7). There was one patient with Crohn's disease of the colon and another with familial polyposis of the colon; both had ileostomies. One of the 16 patients with ulcerative colitis and an ileostomy was studied twice (cases 4 and 18), at an interval of seven months, and thus altogether 19 cases were studied (Table II). The diagnosis in all cases was established on clinical grounds, and by stool examination, sigmoidoscopy, and barium enema, and confirmed at operation and subsequent histological examination of the removed colon; in 12 patients, pre-operative rectal biopsy was performed.

Subtotal colectomy and ileostomy had been performed in eight cases at the time of study, and staged total colectomy and ileostomy in 10 others. In four of this second group a right or left hemicolectomy had preceded total colectomy. When subtotal colectomy was carried out the colon was removed down to the lower sigmoid colon, the upper end of this being exteriorized in the left iliac fossa. Removal of the rectum and sigmoid colon in this series was always done some months after the first operation.

Five patients (three 'new' and two 'established') developed complications. Two (cases 2 and 6) had ileitis and two (cases 10 and 16) had small bowel obstruction. One (case 17) had ileal diarrhoea, to which steatorrhoea was later added after a partial gastrectomy for a duodenal ulcer. Case histories are given in the appendix.

\section{METHODS}

After subtotal colectomy and ileostomy, patients were treated with intravenous fluids in the quantity and of the constitution required by their clinical state. Blood was transfused before and after operation if needed. Potassium was added to the intravenous fluid in some cases. Intra- venous infusions were continued occasionally for eight to 12 days, but in uncomplicated cases were usually stopped four or five days after operation. Starting one or two days post-operatively small amounts of oral fluids were given. About the fourth day most patients were taking a liquid diet and were eating a normal ward diet by the seventh day. After excision of the rectum and sigmoid colon intravenous fluids were needed less often and for a shorter time, the patients returning sooner to an ordinary diet. Some patients made a rapid recovery from the operation especially (but not only) after excision of the rectum. Except when operations interfered, patients with established ileostomies were fed an ordinary diet with free choice of fluid. This also applied to the two patients (cases 12 and 17) from whom ileostomy dejecta were collected while they were at home.

Ten cases were studied during the period immediately after the ileostomy was made, starting on the first to the ninth post-operative day. Study began in one case on the 68th post-operative day. These 11 patients (cases 1 to 11) have been termed 'new ileostomies'. Eight patients (cases 12 to 19) were studied at varying intervals between six months and 15 years after the ileostomy was formed, and have been termed 'established ileostomies' (Table II). Of these, four patients (cases 13, 14, 15, 18) were studied immediately after excision of the rectum and sigmoid colon (starting on the first to the ninth post-operative day), and four (cases 12,16,17,19) were studied one to six and a half years after their last operation (Table II).

As is usual, ileostomy discharge in our patients often did not appear before the second or third day after the ileostomy was formed. At first it was usually scanty and often blood-stained. In most of the 'new' cases in this series ileostomy dejecta were collected from the third or later post-operative day, when the ileostomy was working well.

During periods of study the collection of ileostomy dejecta was complete and continued daily without break in most cases. Unless otherwise stated in the case histories no steroids or extra salts were given during the collection periods.

Ileostomy dejecta were collected in bottles, tins lined with plastic bags, or in ileostomy bags. These were emptied, with negligible loss, into a weighed homogenizer jar (M.S.E. Atomix), which was then re-weighed. The dejecta container was washed out with de-ionized water which was added to the homogenizer jar, which was then weighed again. The material was homogenized and samples removed for analysis while the homogenized dejecta were being agitated. Duplicate and sometimes triplicate samples were analysed.

DETERMINATION OF WATER CONTENT Aliquots, by weight, were transferred to porcelain evaporating basins and dried to constant weight at room temperature in a desiccator, the process taking several days. By allowing for the added water, the water content of the dejecta could be readily calculated. ${ }^{1}$

$1 \%$ water $=100\left(1-\frac{D(F+W)}{F A}\right)$ where $A$ is weight of aliquot, $D$ its weight after drying, $F$ the weight of dejecta, and $W$ the weight of added distilled water. 
DETERMINATION OF SODIUM AND POTASSIUM CONTENT These determinations were made in dejecta and in urine.

Dejecta Aliquots by weight of the diluted dejecta were transferred to hard glass test tubes and their volume made up to about $10 \mathrm{ml}$. with ion-free water. About $1 \mathrm{ml}$. of concentrated nitric acid was added, the contents were mixed by tapping, and the tubes were placed in a boiling water bath for about 10 minutes. At the end of this time, the solid matter had formed large granules. After cooling to room temperature the contents of the tubes were decanted through a small filter paper on to an anion exchange column, prepared as described below. The solid residue in the tube and the filter paper was plentifully washed with ion-free water, the washings being added to the column. Finally, the column was washed with ion-free water, until the total volume of effluent collected was $100 \mathrm{ml}$.

Urine Electrolytes were measured in urine which had been well mixed, being acidified if a phosphate deposit was present. Four $\mathrm{ml}$. was transferred to the anion exchange column, which was washed with ion-free water until $100 \mathrm{ml}$. of effluent had been collected.

ANION EXChANGE COLumn The resin used was Deacidite FF (Permutit Co. Ltd.) in the $\mathrm{Cl}$ form. The column consisted of a glass tube, $2.5 \mathrm{~cm}$. in diameter, with a sintered glass plate at the bottom, on which the column of resin was supported. The flow of liquid from the column was controlled by a tap. A slurry of the resin was poured into the tube, air bubbles being removed by stirring with a thin glass rod and by inversion of the tube. Absence of channelling was confirmed by careful inspection as water was run through the column. Resin was added to the tube to a height of about $15 \mathrm{~cm}$. Water was run out to a few millimetres above the resin level, and the digest, or urine, run slowly on to the resin. The added volume was run slowly through the resin column until the resin surface was just uncovered. The effluent displaced at the other end of the column was discarded. The column was then washed through slowly, all the effluent now being collected.

The column was regenerated after four digests or 10 urines had been run through. Regeneration was carried out with about 1 litre of $10 \%$ ammonium chloride solution followed by 1 litre of ion-free water. Regeneration was complete when the effluent was sodium free and neutral in reaction.

FLAME PHOTOMETRY The sodium and potassium concentration of the effluent was measured using an EEL flame photometer. With this instrument, anion interference, especially from phosphate, is significant. The purpose of the anion exchange column treatment is to remove this interference by replacing all anions by chloride ions. Cation interference also occurs, sodium and potassium mutually interfering with their respective determinations. To allow for cation interference, the approximate sodium and potassium concentrations were first determined and then an accurate measurement made by using standard solutions containing the appropriate amount of the interfering cation, in each case as the chloride. In most cases, in addition to calculating the sodium and potassium in the 24-hour collection of dejecta, their concentration in the dejecta water was also calculated.

EXCHANGEABLE SODIUM This was measured by the method of Miller and Wilson (1953).

\section{RESULTS}

WEIGHT OF DEJECTA The distribution of the weights of the 24-hour ileostomy dejecta in uncomplicated patients is shown in Figure 1. In 64 samples from new ileostomies, the weight ranged from 27 to $1,032 \mathrm{~g}$. with a mean of 324.8 and standard deviation of $222.0 \mathrm{~g}$. In most cases, collection of ileostomy dejecta was begun on the day the ileostomy started to function effectively. In the remainder, collection started after the ileostomy was working well. In 86 specimens from the established cases, the range of weights was 53 to $1,162 \mathrm{~g}$., with a mean of 465.5 and standard deviation of $219 \mathrm{~g}$. The difference in means of the two groups is statistically significant at the $1 \%$ level. In contrast, the weight of colostomy excretion was much lower, averaging $211 \mathrm{~g}$. daily, with a range of 104 to $311 \mathrm{~g}$.

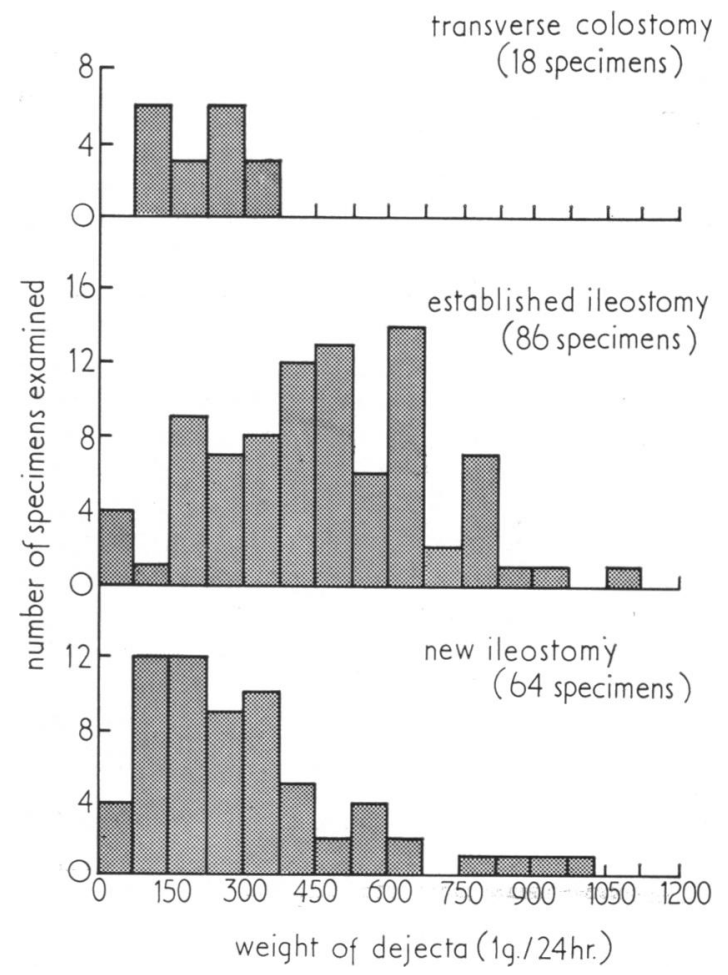

FIG. 1. Distribution of daily weights of dejecta in all patients. 


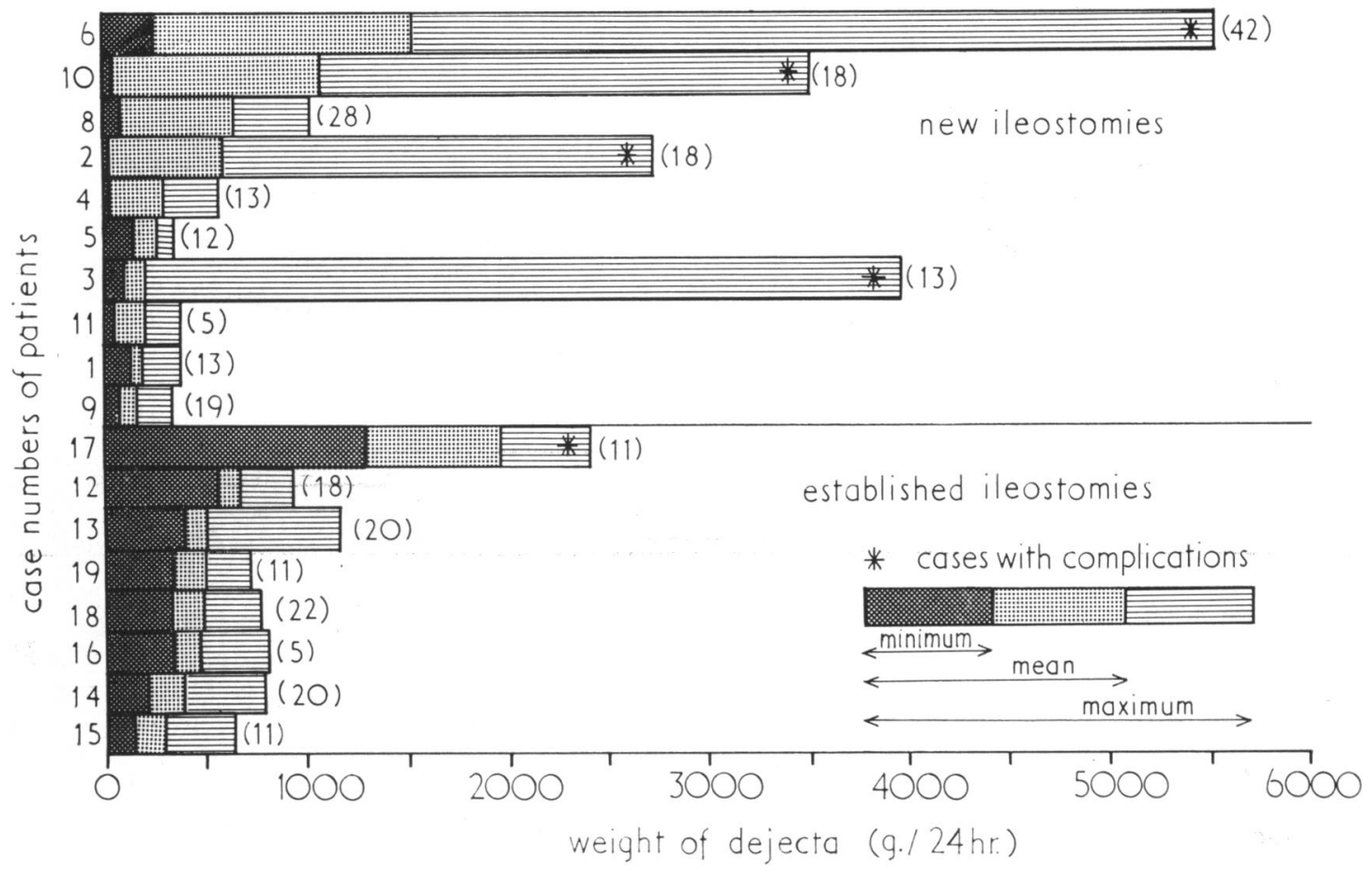

FIG. 2. Daily weights of the ileostomy dejecta of all patients. The ordinate gives the case reference number of each patient, ranked in ascending order of mean daily weight. The number of specimens examined for each patient is given in brackets. Compare the ranking order of patients with that shown in Fig. 6 for daily Na and K excretion.

Figure 2 gives the daily weight of ileostomy dejecta for all patients, arranged in order of decreasing average excretion. On the whole, the weight of dejecta in the uncomplicated cases can be seen to be greater in the established than in the new cases, the range of weights in each patient being narrow. The complicated cases are marked by a great increase in the weight of dejecta excreted on some occasions, the daily maximum being $5.5 \mathrm{~kg}$.

WATER CONTENT The concentration of water was measured in the ileostomy dejecta of nine patients and the colostomy dejecta of one patient, the results being shown in Table III and Figures 3 and 4. In the
57 specimens from four uncomplicated patients with new ileostomies, the water concentration ranged between 84 and $96 \%$ by weight of the dejecta, the mean being $90.8 \%$ and standard deviation $2.27 \%$. In the 51 specimens from three uncomplicated patients with established ileostomies, the concentration varied between 88 and $96 \%$, with a mean of $92.0 \%$ and standard deviation of $1.76 \%$. The difference of the means is statistically significant at the $1 \%$ level, suggesting that in uncomplicated cases the established ileostomy dejecta contain more water than the new ileostomy dejecta.

The effect of codeine on the water concentration of the ileostomy dejecta was observed in case 10 ,

TABLE III

WATER CONTENT OF ILEOSTOMY AND COLOSTOMY DEJECTA

\begin{tabular}{|c|c|c|c|c|c|c|}
\hline & \multicolumn{2}{|c|}{ Uncomplicated Ileostomies } & \multicolumn{3}{|c|}{ Complicated Ileostomies } & \multirow{2}{*}{$\begin{array}{l}\text { Transverse } \\
\text { Colostomy }\end{array}$} \\
\hline & New & Established & $\begin{array}{l}\text { Before Oral } \\
\text { Codeine }\end{array}$ & $\begin{array}{l}\text { After Oral } \\
\text { Codeine }\end{array}$ & $\begin{array}{l}\text { On Oral } \\
\text { Opium }\end{array}$ & \\
\hline $\begin{array}{l}\text { No. of patients } \\
\text { No. of specimens } \\
\text { Range of water concentration }(\%) \\
\text { Mean water concentration }(\%) \\
\text { Standard deviation }(\%)\end{array}$ & $\begin{array}{l}4 \\
57 \\
84-96 \\
90 \cdot 8 \\
2 \cdot 27\end{array}$ & $\begin{array}{l}3 \\
51 \\
88-96 \\
92 \cdot 0 \\
1 \cdot 76\end{array}$ & $\begin{array}{c}8 \\
86-93 \\
89 \cdot 7 \\
2 \cdot 4\end{array}$ & $\begin{array}{l}10 \\
90-97 \\
94 \cdot 4 \\
2 \cdot 1\end{array}$ & $\begin{array}{l}1 \text { (established) } \\
11 \\
86-90 \\
88 \cdot 0 \\
1 \cdot 3\end{array}$ & $\begin{array}{l}1 \\
18 \\
81-91 \\
86 \cdot 0 \\
3 \cdot 9\end{array}$ \\
\hline
\end{tabular}




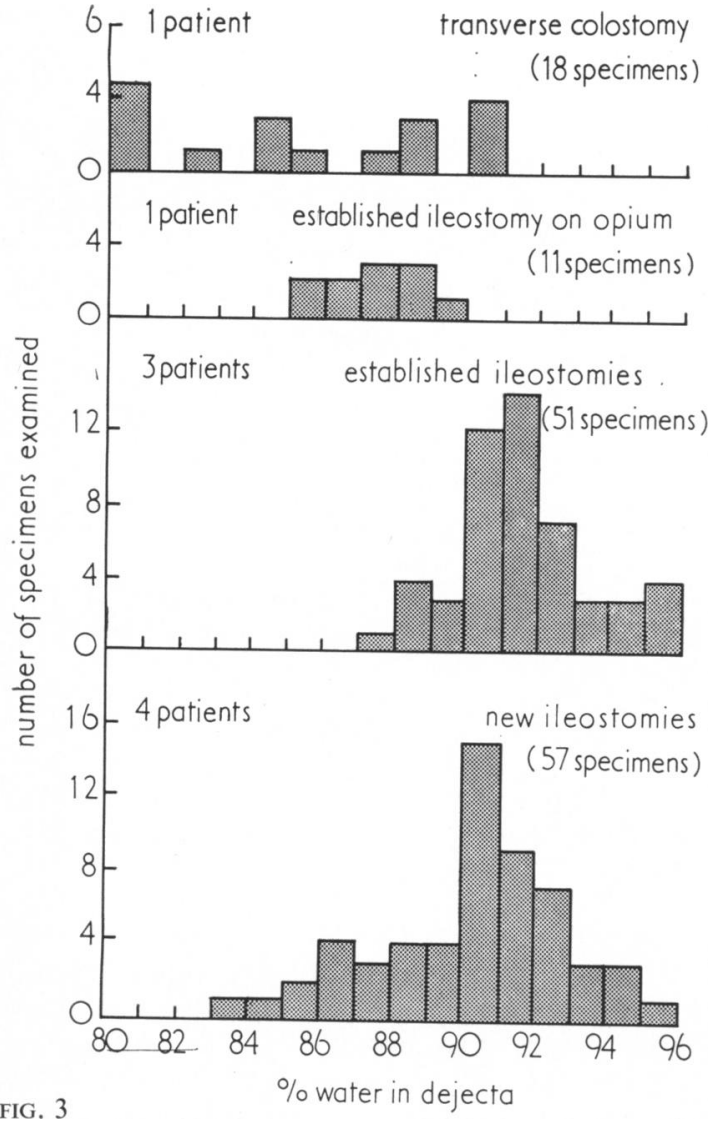

FIG. 3

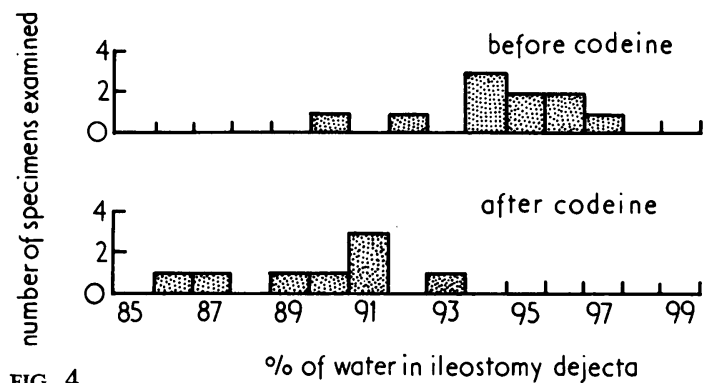

FIG. 4
FIG. 3. Distribution of water concentration of dejecta of all patients.

FIG. 4. Distribution of water concentration of the ileostomy dejecta of case 10 before and after oral codeine.

FIG. 5. Distribution of daily Na excretion in the ileostomy and transverse colostomy dejecta of 'uncomplicated' patients. The number of specimens examined is given in brackets. Values to the right of the vertical arrow are greater than normal.

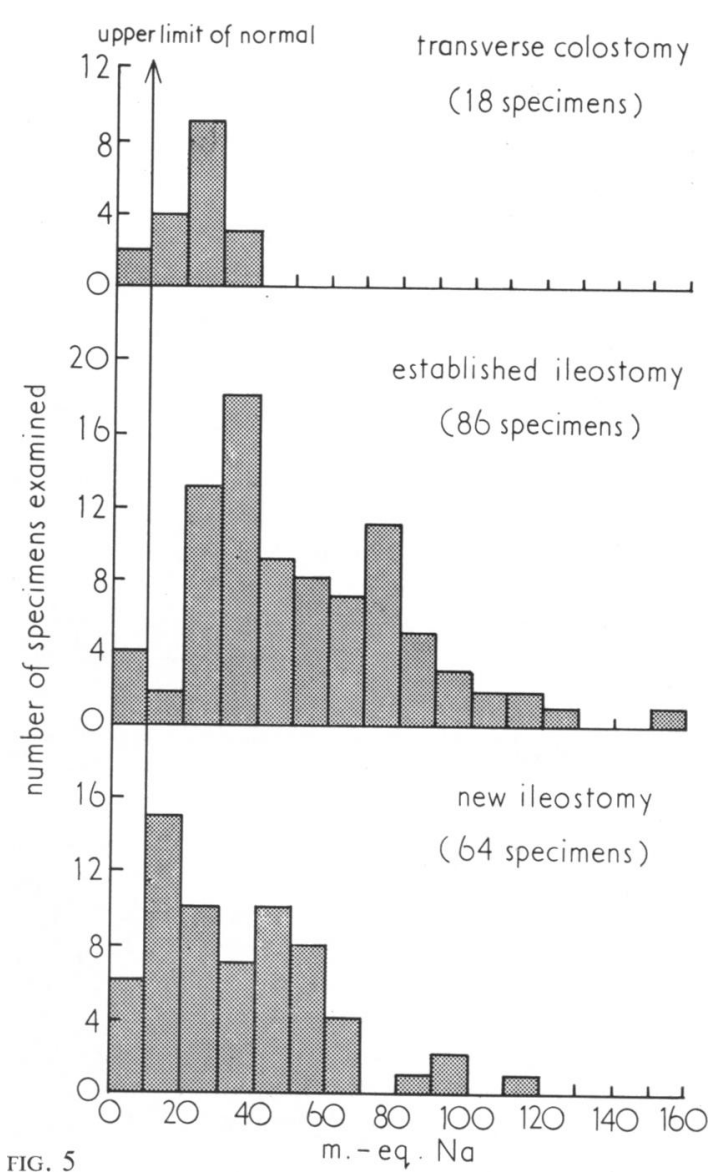

TABLE IV

DAILY SODIUM EXCRETION IN DEJECTA OF NEW AND ESTABLISHED ILEOSTOMIES IN 'UNCOMPLICATED' PATIENTS AND VALUES FOR ONE PATIENT WITH A TRANSVERSE COLOSTOMY FOR COMPARISON

No. of Cases

No. of Specimens
Sodium Excretion (mEq.)

\begin{tabular}{llcllll} 
& & & & Range & Mean & s.d. \\
\cline { 4 - 7 } Ilsostomies & New & 10 & 64 & 4.3 to 114.0 & 35.8 & 23.0 \\
& Established & 8 & 86 & 6.3 to $152 \cdot 1$ & 53.0 & 29.4 \\
Transverse colostomy & 1 & 18 & 7.6 to 37.2 & 22.1 &
\end{tabular}


TABLE V

DAILY POTASSIUM EXCRETION IN DEJECTA OF NEW AND ESTABLISHED ILEOSTOMIES IN 'UNCOMPLICATED' PATIENTS AND VALUES FOR ONE PATIENT WITH A TRANSVERSE COLOSTOMY FOR COMPARISON

\begin{tabular}{lcccccc} 
& No. of Cases & No. of Specimens & & \multicolumn{2}{c}{ Potassium Excretion (mEq.) } \\
\cline { 5 - 7 } & & & Range & Mean & s.d. \\
\hline Ileostomies & New & 10 & 64 & 0.5 to 20.0 & 6.1 & 5.43 \\
& Established & 8 & 86 & 0.5 to 12.0 & 5.5 & 2.69 \\
Transverse colostomy & 1 & 18 & 4.7 to 21.5 & 8.4
\end{tabular}

TABLE VI

CONCENTRATIONS OF SODIUM AND POTASSIUM, SEPARATELY AND COMBINED, IN ILEOSTOMY DEJECTA

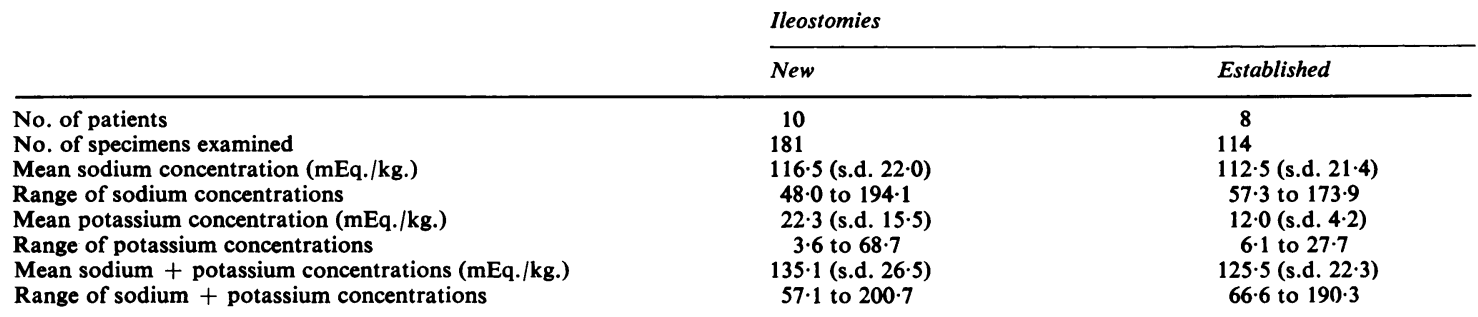

who received $240 \mathrm{mg}$. codeine daily. This patient was a 'complicated' case with a new ileostomy. While taking the drug, the water concentration ranged between 86 and $93 \%$ in eight specimens, and in 10 specimens without the drug the range was 90 to $97 \%$ (Fig. 4). In another patient (case 17), with an established ileostomy, receiving 36 minims of tincture of opium daily, the water concentration of the dejecta varied between 86 and $90 \%$ (Fig. 3).

The water content of ileostomy fluid was much greater than that of the fluid from the patient with the colostomy. In her, it ranged from 81 to $91 \%$ in 18 specimens, the mean being $86.0 \%$ and standard deviation $3.9 \%$ (Fig. 3). The water content of normal faeces has been reported to be about $80 \%$ (Cammidge, 1914) varying with the nature of the diet.

SODIUM CONTENT Almost all specimens of ileostomy fluid from all patients contained more than $10 \mathrm{mEq}$. of sodium, which is the upper limit of sodium excretion in the faeces of normal people (Moore and Ball, 1952). Table IV gives the daily loss of sodium in the dejecta of new and established ileostomies in uncomplicated cases, the distribution of the losses being given in Figure 5. More sodium was lost in the established than in the new cases, the difference being statistically significant at the $1 \%$ level. The range of sodium loss in each case is shown in Figure 6. The range was somewhat greater in cases with established than in those with new ileostomies provided they were uncomplicated. In the complicated cases both range and absolute amount of sodium lost were greatly increased, more so in the cases with new ileostomies than in the patient with an established ileostomy. The maximum sodium loss in a day was $708 \mathrm{mEq}$. (case 6), more than $20 \%$ of the total body sodium of a $70 \mathrm{~kg}$. adult.

POTASSIUM CONTENT The distribution of potassium loss in the dejecta of uncomplicated new and established ileostomies is given in Fig. 7 and the range for all cases is given in Figure 6. The daily loss in the uncomplicated cases is given in Table V. In the established cases, only five specimens of dejecta contained more than $10 \mathrm{mEq}$., the upper limit of the potassium content of normal faeces (Moore and Ball, 1952). There were 14 specimens above this level in the new ileostomies, but the number was still small. The excretion was rather greater in the complicated cases, the maximum (case 3) being $104 \mathrm{mEq}$. in a day. This is about $3 \%$ of the total body potassium for a $70 \mathrm{~kg}$. adult. There was no statistically significant difference between the mean excretion of potassium in the new and established uncomplicated ileostomies. The potassium loss through the transverse colostomy was a little higher than that through the ileostomies.

CONCENTRATION OF SODIUM AND POTASSIUM The concentration of these electrolytes in the ileostomy dejecta of all patients is given in Table VI, the distribution of concentrations being shown in Figure 8. The concentration of sodium in established and new ileostomies was essentially the same, the mean of all specimens of dejecta being $114.9 \mathrm{mEq}$. per $\mathrm{kg}$. On the basis of our value for the mean water concentration of $91 \%$, the calculated sodium concentration was about $126 \mathrm{mEq}$. per litre of ileostomy water, 


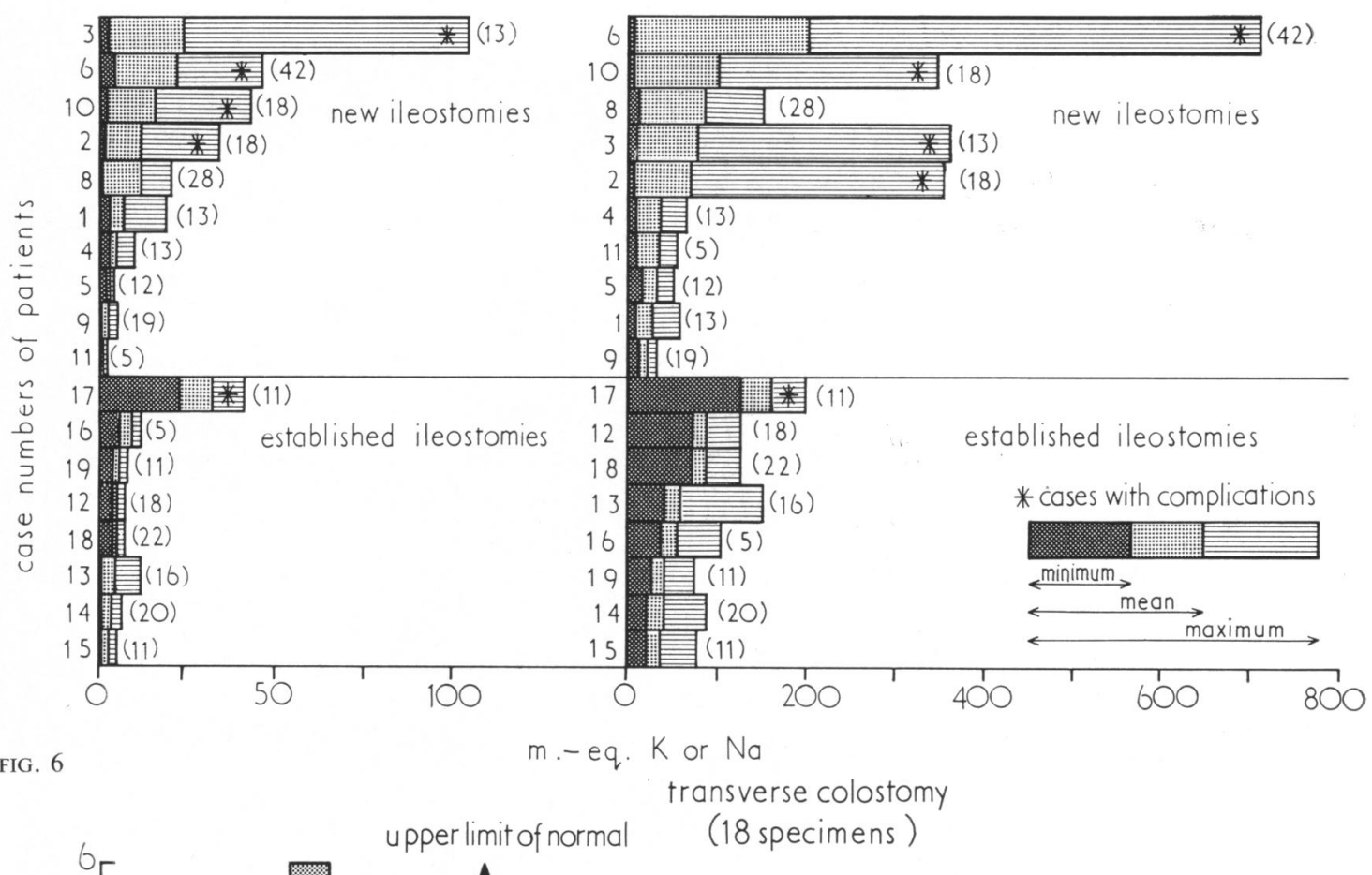

FIG. 7

$$
\text { m. - eq. } K
$$

FIG. 6. Daily excretion of $K$ and $\mathrm{Na}$ in the ileostomy dejecta of all patients. The ordinate gives the case reference number of the patients, ranked in ascending order of mean $\mathrm{K}$ and $\mathrm{Na}$ excretion. The number of specimens examined for each patient is given in brackets. The figure shows the minimum, mean, and maximum values of daily $K$ and Na excretion.

Note the differing ranking order of the patients for $\mathrm{K}$ and $\mathrm{Na}$ excretion. Compare with Fig. 2.

FIG. 7. Distribution of daily $K$ excretion in the ileostomy and transverse colostomy dejecta of 'uncomplicated' patients.

The number of specimens examined is given in brackets.

Values to the right of the vertical arrow are greater than normal. 


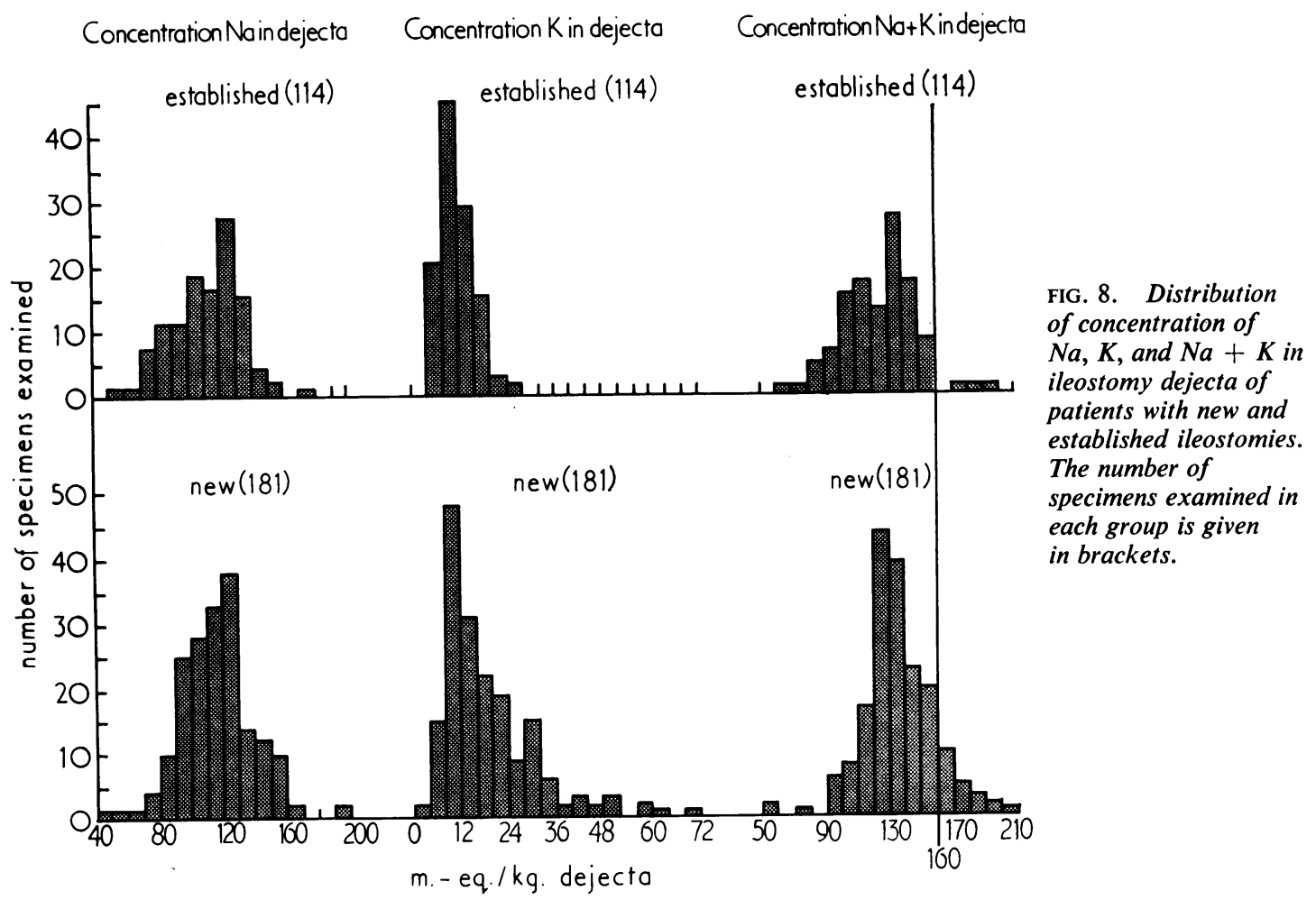

i.e., $87 \%$ of the average normal plasma sodium concentration of $145 \mathrm{mEq}$. per litre.

The concentration of potassium, on the other hand, was greater in the new than in the established ileostomies, the difference being statistically significant at the $1 \%$ level. This difference, however, may not represent a difference in potassium concentration in the fluid part of the ileostomy dejecta, but may be related to a difference in their cellular content, particularly mucosal cells. In the method used for the estimation of potassium, treatment with nitric acid would liberate intracellular potassium, which would then be measured with the potassium already in solution.

The combined concentration of sodium and potassium was higher in the dejecta from new than in that from established ileostomies, the difference being significant at the $5 \%$ but not at the $1 \%$ level. The difference was due to the potassium component and may, therefore, not be as significant as it appears. In a few cases, the sum of sodium and potassium was well in excess of $160 \mathrm{mEq}$. per litre of ileostomy water (which is roughly isotonic) calculated as before, assuming the water concentration to be $91 \%$. While in some instances this may have been due to the potassium effect described above, this explanation will not suffice for those instances where the sodium concentration alone exceeded $160 \mathrm{mEq}$. per litre. A possible explanation was some undetected error of technique.

EFFECT OF ORAL SODIUM AND POTASSIUM CHLORIDE The effect of oral sodium and potassium chloride on the composition of the ileostomy dejecta was studied in two patients. The first, case 18 , had an established ileostomy. After a control period of five days on a normal hospital diet she was given $2 \mathrm{~g}$. daily of $\mathrm{KCl}$ and $\mathrm{NaCl}$ during four consecutive alternating three-day periods, each separated by one control day. The composition of the dejecta was measured in all five periods. The average daily excretion of sodium and potassium was calculated for the control and for each test period. The results are shown in Figure 9. From Fig. 9, it can be seen that the excretion of sodium from the ileostomy was increased, in all the test periods, above the control period level, while the urinary sodium excretion fell in the first three test periods. On the other hand, the excretion of potassium in the dejecta hardly changed, the oral dose being equal to the potassium excreted in the urine. During the test periods the weight of dejecta rose steadily from $333 \mathrm{~g}$. per day in the control period to $632 \mathrm{~g}$. per day in the final test period, an increase of about $100 \%$. The water content of the 


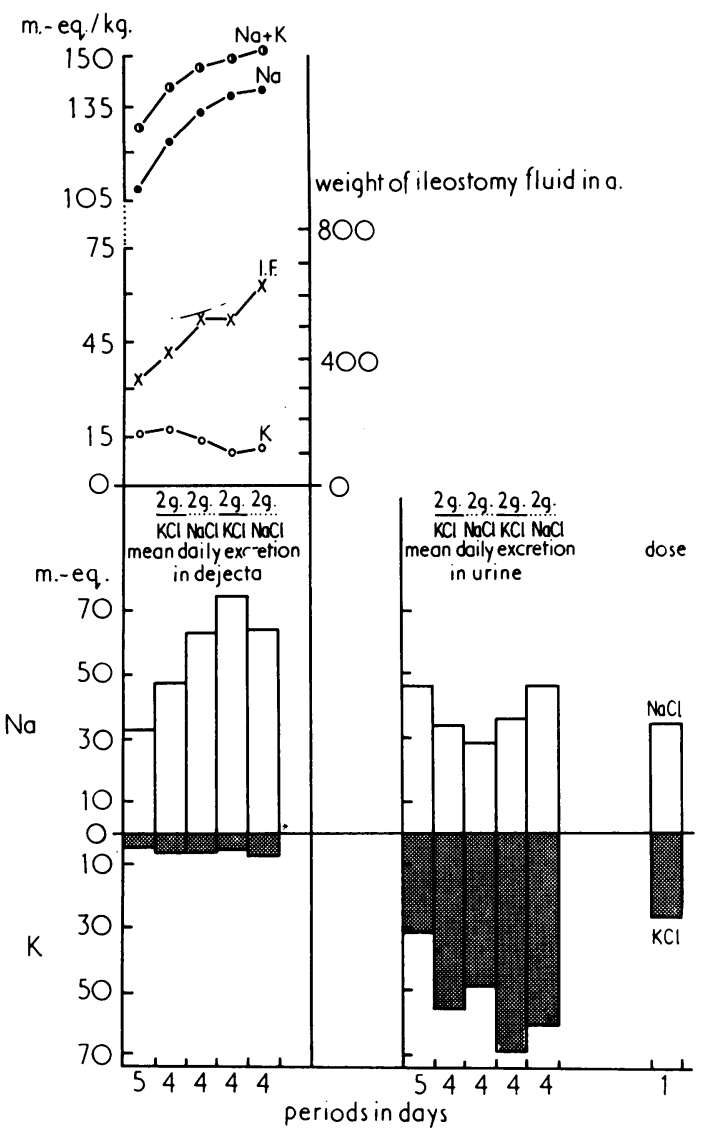

FIG. 9. Effects, in case 18 , on the excretion of $\mathrm{Na}$ and $\mathrm{K}$ in ileostomy dejecta and urine of oral $\mathrm{NaCl}$ and $\mathrm{KCl}$ given during alternating periods. Each column and corresponding points on the graphs give the average value of the parameter for the collecting period ( five days for the control, four days for the test period). Ileostomy dejecta data are shown on the left and urinary data for the same periods are shown on the right of the figure. The daily dose of $\mathrm{Na}$ and $\mathrm{K}$ is shown on the extreme right. The graphs show average daily weights, and $\mathrm{Na}, \mathrm{K}$, and $\mathrm{Na}+\mathrm{K}$ concentrations of ileostomy dejecta during these periods.

dejecta was higher during the test periods than in the control period, the figures being $90.8 \%$ for the control period and $92 \cdot 0,92 \cdot 3,92 \cdot 8$, and $92.5 \%$ for the respective test periods. The concentration of sodium in the ileostomy dejecta rose from $109 \mathrm{mEq}$. per litre in the control period to $140 \mathrm{mEq}$. per litre in the final test period. The increased sodium concentration and increased total sodium content of the ileostomy dejecta occurred both when sodium and potassium chlorides were given by mouth. On the other hand, potassium concentration of the dejecta fluctuated irregularly and the combined concentra- tion of sodium and potassium reflected essentially the changes in sodium concentration.

In the second patient (case 8) with a new ileostomy, the effect of oral sodium and potassium chloride has been shown in a different way. This patient, after a control period of 16 days, was given $3 \mathrm{~g}$. $\mathrm{NaCl}$ $(51.4 \mathrm{mEq}$.) and $3 \mathrm{~g}$. $\mathrm{KCl}(40.2 \mathrm{mEq}$.) daily for 12 days. The mean daily weight and sodium and potassium content of the dejecta were calculated for each period, the results being shown in Figure 10. Urinary loss was not measured in this patient. The mean daily weight of the dejecta in the test period was more than $50 \%$ greater than in the control period, the mean daily loss of sodium more than doubling and the mean daily loss of potassium

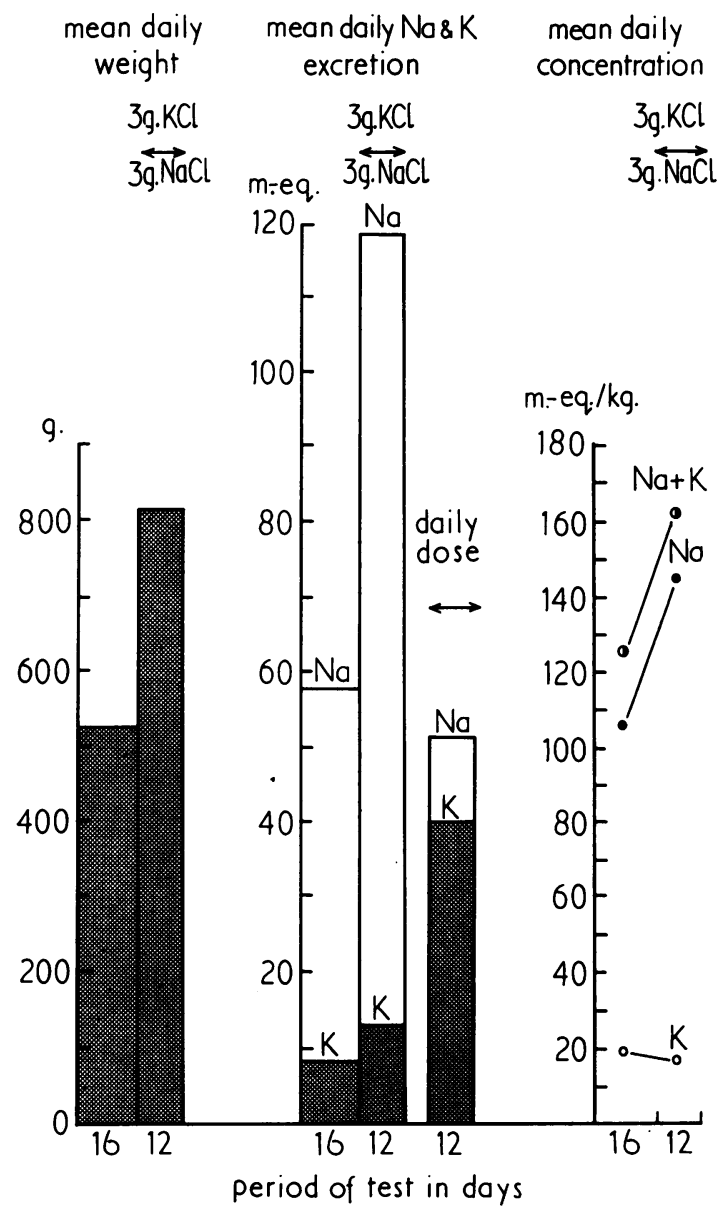

FIG. 10. Effect, in case 18, of the oral administration of $\mathrm{NaCl}+\mathrm{KCl}$ on the $\mathrm{Na}$ and $\mathrm{K}$ excretion in the ileostomy dejecta and their weights. Columns give the mean daily values for two consecutive collecting periods (control for 16 days, test for 12 days). The graph gives the mean daily concentrations of $\mathrm{Na}, \mathrm{K}$, and $\mathrm{Na}+\mathrm{K}$ for these periods. 
increasing by about $60 \%$. These results are more significant when considered in terms of the actual increase in loss of sodium and potassium in the test period compared with the control. On an additional daily intake of $51.4 \mathrm{mEq}$. of sodium, the increased loss in the dejecta in the test period averaged $61 \mathrm{mEq}$., while on an additional daily intake of $40.2 \mathrm{mEq}$. of potassium, the increased loss in the dejecta was only $5 \mathrm{mEq}$. The concentration of sodium rose considerably and the concentration of potassium fell slightly in the test period compared with the control period, while the combined concentration of sodium and potassium paralleled that of sodium alone.

EFFECT OF ORAL WATER It was possible, in case 19, to study the effect of additional water by mouth on the weight of the ileostomy dejecta. This patient developed a low salt syndrome with severe postural hypotension, dehydration, oliguria, and almost complete disappearance of sodium from the urine. At this time her 24-hr. exchangeable sodium was $32 \mathrm{mEq}$. per $\mathrm{kg}$. bodyweight, the average normal value being about $45 \mathrm{mEq}$. per $\mathrm{kg}$. bodyweight. The syndrome probably arose from a combination of prolonged low sodium intake (as a therapeutic measure for hypertension) and prolonged excessive loss of sodium through an overactive ileostomy. During treatment she was given intravenous saline, 1 to 41 . daily, for 10 non-consecutive days. Figure 11 shows the relationship between the volume of oral fluid and the weight of ileostomy dejecta on each day. Daily oral fluid intake varied between 850 and

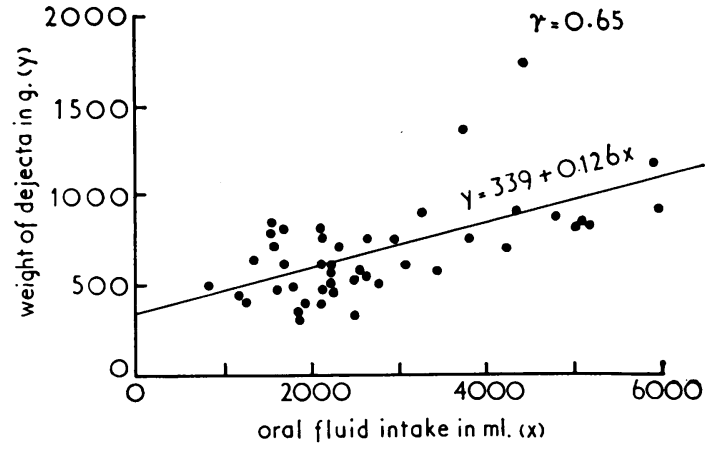

FIG. 11. Correlation between weight of ileostomy dejecta and oral fluid intake in case 19.

$6,000 \mathrm{ml}$. and dejecta weight between 300 and $1,750 \mathrm{~g}$. The correlation between oral fluid intake and dejecta weight is well marked, the correlation coefficient $r$ being +0.65 . If the 10 days on which intravenous saline was given are excluded from the series, $\mathrm{r}$ was even greater, being $+\mathbf{0 \cdot 6 7}$.

EFFECT OF ORAL CODEINE During the period of investigation case 10, who had a new ileostomy, developed small bowel obstruction, due to intraabdominal abscesses. After drainage, the obstruction was relieved and the ileostomy became overactive, resulting in marked loss of sodium, potassium, and water, the patient becoming depleted of potassium. She was given orally $60 \mathrm{mg}$. codeine four times daily for 10 days and $1.5 \mathrm{~g}$. potassium chloride
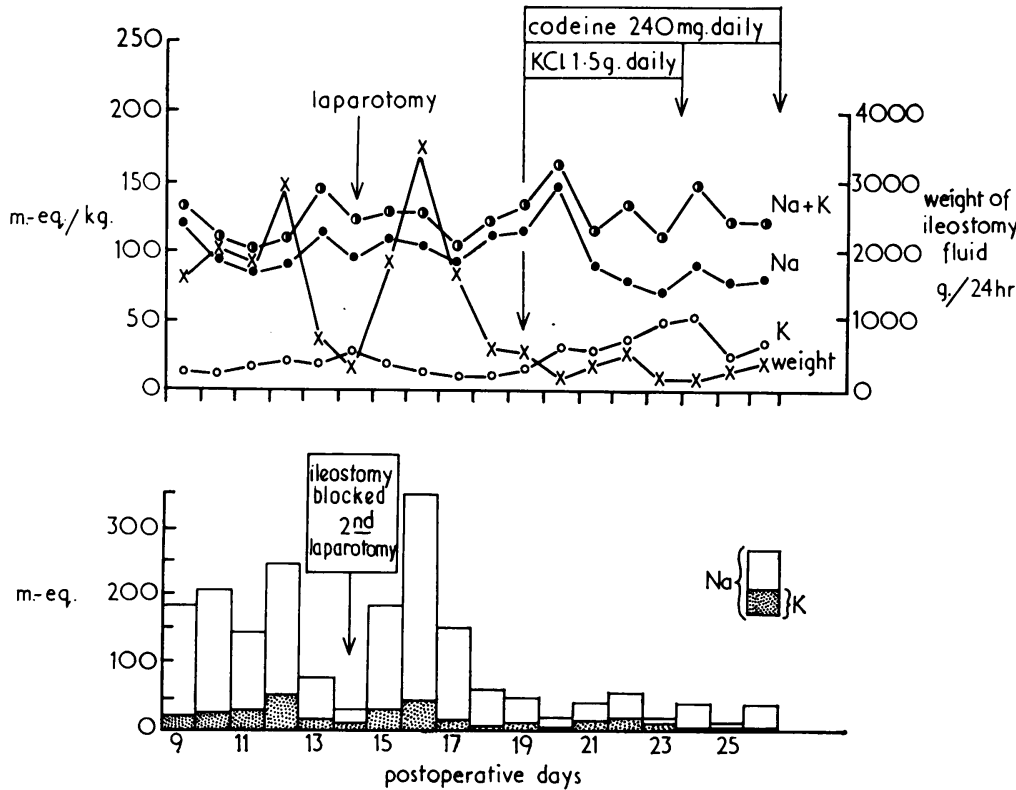

FIG. 12. New 'complicated' ileostomy (case 10). Excretion of $\mathrm{Na}$ and $\mathrm{K}$ in the ileostomy dejecta, and their weight, in a patient who developed intestinal obstruction after subtotal colectomy. The figure shows the results of relieving the obstruction and oral treatment with codeine and $\mathrm{KCl}$. 
(20.1 mEq.) daily for the first of these days. The effect of these measures on the ileostomy dejecta is shown in Figure 12. On this regime, there was a marked and sustained fall in the weight of ileostomy dejecta and in the daily loss of sodium and potassium. The concentrations of sodium and potassium separately and together fluctuated, but, on the whole, were about the same as in the period before codeine. It was not possible to obtain complete collections of urine during the investigation.

\section{DISCUSSION}

WEIGHT OF DEJECTA The weight of ileostomy dejecta in new and established ileostomies in the uncomplicated cases of our series agrees well with those reported by other authors, assuming weight and volume to be roughly interchangeable. Crawford and Brooke (1957) found daily volumes of ileostomy dejecta of about $500 \mathrm{ml}$. in established cases, with volumes up to $2,000 \mathrm{ml}$. in the first few days. Fowler et al. (1959) found weights of 400 to $500 \mathrm{~g}$. by the seventh to eighth day. Smiddy et al. (1960) reported volumes of 300 to $500 \mathrm{ml}$. in established cases and 200 to $500 \mathrm{ml}$. in new ileostomies; Kramer et al. (1962) reported a mean weight of $507 \mathrm{~g}$./day in seven established cases. In our series, the mean daily weight of dejecta for new cases was $325 \mathrm{~g}$. and for established cases was $466 \mathrm{~g}$.

An interesting point about the weight of the dejecta was the significant increase in weight in established compared with new ileostomies. As the established ileostomy patients were, for the most part, healthy at the time of the investigation and the new ileostomy group were recovering from a severe operation after varying periods of ill-health of some severity, the two groups are hardly statistically comparable. The increased weight of dejecta could be a reflection of the better state of health of the established cases, associated with a bigger food intake. The mechanism of this is discussed later.

WATER CONCENTRATION Data on the water content of ileostomy dejecta have been published only by Kramer et al. (1962) who found a mean value of $92.1 \%$ (range 90.1 to $93.7 \%$ ). In our cases, there was a statistically significantly higher concentration of water $(92.0 \%)$ in the established than in the new ileostomies $(90.8 \%)$. This may be a consequence of the better nutritional state of the patients with established ileostomies, the increase in water being related to the increased sodium loss in the dejecta of these patients compared with those with new ileostomies. This, if true, would also account for the observed increase in weight. The water concentration reported here for established cases agrees well with the $92 \cdot 1 \%$ reported by Kramer et al. (1962).
SODIUM AND POTASSIUM IN THE DEJECTA As shown in Table $I$, with the exception of the results of Crawford and Brooke (1957), later explained (Crawford and Brooke, 1958), the sodium concentrations of our series of new ileostomies agreed well with those reported by recent authors, but were a little lower than those of the older authors. On the other hand, potassium concentrations were rather higher in our series. In established ileostomies, the sodium and potassium concentrations in our series were very similar to those reported by other authors, except for the very low result (Table I) of Lockwood and Randall (1949). The daily loss of sodium and potassium in our uncomplicated cases agreed well with the findings of Smiddy et al. (1960), but was somewhat lower than that of Fowler et al. (1959). It is unlikely that the differences between our results and those of other recent authors are significant because of the great variability in the groups of patients studied, as well as the differences in operative technique, post-operative treatment, and technical laboratory procedures inevitable in experimental medicine. On the whole, it can be concluded that in both new and established ileostomies, sodium concentration is about $120 \mathrm{mEq}$. per kg., the water content about $91 \%$, potassium concentration is variable but less than $25 \mathrm{mEq}$. per $\mathrm{kg}$., and the osmolarity of the dejecta is about isotonic. Daily losses of sodium are usually less than $100 \mathrm{mEq}$. and potassium less than $20 \mathrm{mEq}$.

EFFECT OF ADDED SODIUM AND POTASSIUM CHLORIDE The addition of either sodium chloride or potassium chloride to the diet (Figs. 9 and 10) resulted in an increased loss of sodium in the ileostomy dejecta and in an increase in their weight, with little change in the potassium loss. Urinary sodium excretion was diminished when either salt was given, but urinary potassium excretion increased only after administration of potassium chloride.

These results can be explained on the basis of an osmotic effect being produced by the orally administered sodium and potassium chloride, leading to diminished water absorption. This would result in an increased weight of ileostomy dejecta, an increased water content, and an increased sodium concentration. All these effects were observed. What is remarkable is that, in these tests, net transfer of potassium was so large (as shown by its high excretion in the urine) while that of sodium was so small. This was probably due to the small difference in concentration between intestinal sodium and extracellular sodium, which led to a small net transfer of sodium across the wall of the small intestine, and the very large concentration gradient for potassium, which gave rise to a large net transfer. 
These findings suggest that resalination with potassium can readily be effected by oral administration of potassium chloride, which is efficiently absorbed. However, regard must be paid to the increase in water and sodium loss in the ileostomy dejecta during potassium chloride administration. Resalination with sodium by orally administered sodium chloride may be much more difficult to achieve because of the increased loss of sodium in the ileostomy dejecta. Rehydration with oral fluids may also be difficult, as shown in case 19 , because of the water loss induced by the load. Absorption of water and sodium in the oral treatment of water and sodium depletion in patients with an ileostomy can probably be improved by the concurrent administration of codeine or opium.

Although intravenous therapy is a helpful adjunct to oral salt and water therapy, it is sometimes difficult to restore fluid and salt balance because of the continued loss of salt and water through the ileostomy. Further, intravenous therapy promotes an increased urinary flow. This effect was shown in case 19, in whom, during the period of intravenous fluid administration, daily urinary output varied between 643 and 4,173 $\mathrm{ml}$. daily (mean 1,716 ml.); during the rest of the period of investigation, urinary output was 280 to $2,920 \mathrm{ml}$. (mean $780 \mathrm{ml}$.).

It is of interest that in these patients and, to an even greater extent in case 19, an increased loss of sodium through the ileostomy should occur in the presence of sodium conservation by the kidney. In case 19 , sodium was almost absent from the urine when the ileal loss averaged $41.5 \mathrm{mEq}$. per day and her 24 hour exchangeablo sodium was $32 \mathrm{mEq}$. per $\mathrm{kg}$., which is about $70 \%$ of normal. The increased loss of sodium in the ileostomy dejecta in the presence of renal conservation in this patient suggests that net sodium transfer in the small intestine can be independent of the body stores of sodium.

RELATIONSHIP BETWEEN WATER INTAKE AND WEIGHT OF ILEOSTOMY DEJECTA The marked correlation between fluid intake by mouth and weight of ileostomy dejecta found in case 19 suggests that fluid intake is an important factor in determining the bulk of the dejecta. In this patient, the relationship was even more remarkable as she was dehydrated and oral water was given in an attempt to rehydrate her; further, in spite of a reduced exchangeable sodium, the serum sodium concentration was only slightly lowered. The effect of oral water and salts in increasing the weight and sodium content of the ileostomy fluid would explain the increased weight and sodium content of the ileostomy dejecta observed in patients with established ileostomies. These patients form a relatively healthy group when compared with those with recent ileostomies. If, as a consequence of their better state of health, they consume a more liberal diet than the recent ileostomy patients, their dejecta would become bulkier. Kramer et al. (1962) found that neither drinking as much as 31 . of water a day nor varying the diet (except the addition of prune juice) increased the weight of ileostomy dejecta in established cases. However, the changed diet may still be the cause of the increased weight of dejecta when the patients with established ileostomies are compared with those with recent ones.

EFFECT OF CODEINE It was observed previously that oral administration of potassium chloride caused an increased loss of sodium and water in the ileostomy dejecta. The expected increase did not occur in case 10 , who received oral potassium chloride in combination with $240 \mathrm{mg}$. codeine daily. However, the progress of this patient was complicated by a brief period of intestinal obstruction; some of her improvement may well have been due to the freeing of the ileostomy.

In case 17 , who received opium and, later, codeine, it was found that dehydration could be prevented only by continued administration of the drug. Loss of water and sodium through the ileostomy when the drug was discontinued was so marked that he became seriously ill in a few days.

These findings suggest that the oral administration of codeine (or opium) may be sufficient for rehydration and resalination in some patients, receiving water and salts by mouth. In other cases, intravenous fluids and salts may be required in addition.

\section{APPENDIX}

CASE HISTORIES

CASE 1 A woman aged 24 had a history of intermittent bloody diarrhoea for 17 years, latterly becoming more severe. Examination revealed changes of severe chronic ulcerative colitis and a rectal stricture. There was no evidence of carcinoma. Subtotal colectomy was performed and an ileostomy made. Ileostomy dejecta were examined for 13 days starting on the third post-operative day.

CASE 2 A woman aged 29 had continuous bowel symptoms for five months. She had severe ulcerative colitis involving all the colon but sparing the rectum. Serum electrolytes were normal in concentration. She was one of the first patients to be treated with cortisone, which she received for six weeks with potassium supplements. She improved, but relapsed six months later, the rectum now becoming involved. The serum sodium level was $135 \mathrm{mEq}$./1. A subtotal colectomy was performed and an ileostomy made. Ileostomy dejecta were examined for 18 consecutive days starting on the third post-operative day. Twelve days after operation the serum sodium level was 123 and potassium $5.5 \mathrm{mEq}$./l. Recovery was smooth 
until the seventeenth post-operative day when she had colicky abdominal pain. The ileostomy only worked intermittently. The next day the blood pressure fell to $86 / 64 \mathrm{~mm}$. $\mathrm{Hg}$ and the pulse rose to 108 per minute. She continued to have windy pains and was cold and sweating. The serum sodium level was 110 and potassium $6.6 \mathrm{mEq}$. $/ 1$. She died early on the nineteenth post-operative day. At necropsy the lower end of the ileum contained numerous shallow punched-out ulcers. The mucosa was hyperaemic. There was no obstruction. The macroscopic and microscopic appearances of the suprarenal glands were normal.

CASE 3 A married woman aged 35 was transferred from another hospital with a five weeks' history of bloody diarrhoea. She had severe ulcerative colitis. The haemoglobin was $8.8 \mathrm{~g} . \%$ and the leucocytes numbered 13,000 per c.mm. (neutrophils $89 \%$ ). The serum sodium level was 127 , the potassium 5.5 , and the chloride $87 \mathrm{mEq} . / 1$. The blood pressure fell to $88 / 68 \mathrm{~mm}$. Hg but she responded to a transfusion of 3 pints of blood. She became jaundiced (serum bilirubin $4.6 \mathrm{mg} . \%$ ) and drowsy. The abdomen became distended because of severe dilatation of the colon. Five days after admission a subtotal colectomy was performed with creation of an ileostomy. Oral neomycin and parenteral penicillin and streptomycin were given for three days before operation. The serum sodium level was 135 , the potassium $3 \cdot 1$, and the chloride $95 \mathrm{mEq} . / \mathrm{l}$. pre-operatively. At operation the colon was dilated and severely inflamed. It was perforated in several places and part of the anterior wall of the descending colon was formed by the posterior wall of the parietes. Extensive faecal soiling of the peritoneum took place. The patient made an uneventful recovery. Ileostomy dejecta were investigated for 13 days starting on the eighth post-operative day. On the eleventh post-operative day she was given intravenously 2 litres of $0.18 \%$ saline and $5 \%$ glucose solution, and two days later 2 litres of $0.9 \%$ saline and one of $5 \%$ glucose in $0.18 \%$ saline solution.

CASE 4 A woman aged 44 with ulcerative colitis affecting all the colon for 13 years was seen during a relapse. She deteriorated despite treatment with hydrocortisone retention enemata and oral prednisone. The serum sodium level was 135 , potassium $6 \cdot 6$, and chloride 90 mEq./1. Subtotal colectomy was performed and an ileostomy made. Cortisone, $100 \mathrm{mg}$., was given on the day of the operation, $200 \mathrm{mg}$. the next day, and in falling dosage for six days afterwards. The post-operative course was uneventful. Ileostomy dejecta were investigated for 13 consecutive days, starting on the third post-operative day. During the first two days of the collection period 75 to $100 \mathrm{mg}$. cortisone was given, and during the next two days 25 to $37.5 \mathrm{mg}$. was given. The day after the operation the serum sodium level was 129 , potassium $4 \cdot 7$, and chloride $87 \mathrm{mEq}$./1. A week later the serum sodium level was 126 , potassium $4 \cdot 7$, and chloride $97 \mathrm{mEq} . / \mathrm{l}$.

CASE 5 A woman aged 24 was admitted, very ill, to hospital with a history of rectal bleeding, loss of weight, and low back pain for three and a half months. Diarrhoea had been present for 10 days. Examination showed severe ulcerative colitis involving the whole colon. Subtotal colectomy was performed and an ileostomy made. There was no improvement in her general state and three weeks later the rectum and sigmoid colon were removed. Two large perirectal abscesses were found. The sigmoid colon was very septic and had perforated. The patient made a slow recovery. Ileostomy dejecta were collected for 12 days starting on the sixty-eighth day after the first operation.

CASE 6 A 23-year old man had had unremitting severe ulcerative colitis for two and a half years. (This case has been briefly reported by Coghill, Lubran, McAllen, Edwards, and Richenberg, 1956, Figure 2 and Table XII.) $\mathrm{He}$ had recently suffered from oedema of the feet and ankles, heavy albuminuria, and hyalogranular casts in the urine. Nephritis or amyloid disease were considered as diagnoses. The urine became free of albumin. The serum sodium level was 139 , potassium $4 \cdot 5$, and chloride $104 \mathrm{mEq}$./l. at the time when a subtotal colectomy was performed and an ileostomy made. The last few inches of the ileum were involved and the lowest 12 inches were removed. Ileostomy dejecta and urine were collected for the first $\mathbf{4 2}$ days after the operation. From the fourth postoperative day he vomited, there was excessive ileal loss, and his condition deteriorated. Much blood was present in the ileostomy dejecta. Loss of water and sodium mounted and reached a peak on the nineteenth day after operation when he lost 5,505 g. ileostomy fluid containing $708 \mathrm{mEq}$. of sodium. Potassium loss did not exceed $46 \mathrm{mEq}$. per day. He received large amounts of intravenous fluid, saline, plasma, and blood but the serum sodium level fell to 123 , potassium to $3 \cdot 1$, and chloride to $89 \mathrm{mEq}$./l. As obstruction of the small intestine was feared laparotomy was performed on the twentieth postoperative day. There was a remarkable absence of adhesions. The whole of the small intestine was dilated and its wall thickened, but there was no mechanical obstruction. The condition appeared to be due to an extensive jejuno-ileitis. The patient was given cortisone, $100 \mathrm{mg}$. daily, intravenous water, sodium, and potassium, and oral neomycin and opium. The ileostomy discharge was partially controlled. Four weeks after the ileostomy was made (one week after the second operation) the four-hour sodium space was $217 \mathrm{ml} / \mathrm{kg}$. (normal 260 to 300 ) indicating some degree of dehydration, and the exchangeable sodium $16 \cdot 3 \mathrm{mEq}$. $/ \mathrm{kg}$. (normal 36 to 48 ). The exchangeable potassium was just above the lower level of the normal range. These values were raised to normal levels within one week by vigorous water and salt therapy. He was discharged from hospital 10 weeks after the first operation. He was readmitted on three further occasions with an overactive ileostomy, dehydration, hypotension, low serum sodium and potassium levels, and paralytic ileus. He survived an attack of staphylococcal pneumonia. On his last admission the serum sodium level was 124 , potassium $2 \cdot 9$, chloride 107 , and bicarbonate $12.2 \mathrm{mEq}$./l. It was impossible to maintain an adequate water and electrolyte balance and the patient died eight months after his first operation.

Post-mortem examination showed general peritonitis, hypertrophy and fibrosis of the muscularis mucosae of the small intestine; petechiae and shallow ulcers in the 
jejunum; well-marked amyloidosis in the spleen; very early amyloid changes in the liver and kidneys.

CASE 7 A woman aged 48 had a 12-year history of almost unremitting ulcerative colitis affecting only the left half of the colon. A left hemicolectomy was performed and transverse colostomy made. The colostomy dejecta were analysed for 18 consecutive days starting on the sixth post-operative day. The patient made an uninterrupted recovery.

CASE 8 A man aged 33 years with a history of ulcerative colitis for three years was admitted to hospital in relapse. Examination showed that the colon was severly affected up to the hepatic flexure. At this time the serum sodium level was 135 , potassium $3 \cdot 3$, and chloride $89 \mathrm{mEq} . / 1$. He was given $40 \mathrm{mg}$. prednisone, $3 \mathrm{~g}$. potassium chloride, and $1 \mathrm{~g}$. tetracycline daily. The prednisone was continued for five weeks but his condition deteriorated and a subtotal colectomy was performed with an ileostomy. Ileostomy dejecta and urine were examined for 28 days, starting on the first post-operative day. The serum electrolyte levels before and after operation were as follows:

\begin{tabular}{crccc} 
& Days & $N a$ & $K$ & $\begin{array}{l}\text { Cl } \\
(m E q . / l .)\end{array}$ \\
\hline Before operation & 10 & 135 & $3 \cdot 9$ & 92 \\
& 2 & 135 & $4 \cdot 1$ & 92 \\
After operation & 3 & 119 & $4 \cdot 2$ & 102 \\
& 5 & 139 & $3 \cdot 4$ & - \\
& 25 & 125 & $4 \cdot 2$ & -
\end{tabular}

From the seventeenth to the twenty-eighth post-operative days he was given daily $3 \mathrm{~g}$. each of potassium and sodium chloride. The effect of these salts on the ileostomy dejecta is shown in Figure 10.

CASE 9 A woman aged 46 was admitted to hospital in her fifth attack of bloody diarrhoea. Her first had occurred 18 months previously when sigmoidoscopy showed a normal rectal mucosa and a barium enema radiograph revealed only diverticulosis of the descending colon. Biopsy of a perianal fistula now showed non-specific inflammatory granulation tissue with some foreign body type giant cells. The rectal mucosa was inflamed and ulcerated and biopsy of it strongly suggested Crohn's disease (Dr. A. Knudsen and Dr. B. Morson). A barium enema radiograph indicated that only the left half of the colon was affected. Malabsorption was not present and radiologically the small bowel was normal. Five weeks after discharge from hospital she was re-admitted with another relapse (temperature $102^{\circ} \mathrm{F}$.). A left hemicolectomy was performed and a transverse colostomy created. Histological examination of the colon confirmed the diagnosis of Crohn's disease. At operation the right colon and ileum appeared to be normal. Eventually the rectum and right half of the colon, with the terminal ileum, were resected and an ileostomy made. The ileum was normal, the mucosa of the caecum and ascending colon was somewhat reddened, the right half of the colon contained scanty diverticula, and the rectum was ulcerated. Ileostomy dejecta were examined for 19 days, starting on the eighth day after the ileostomy was formed. The effect of oral sodium and potassium chloride on the dejecta was measured.

CASE 10 A woman aged 20 who had suffered from ulcerative colitis for three years was admitted to hospital in relapse. The colon was involved as far up as the distal transverse colon. Her condition deteriorated in spite of oral prednisone, neomycin, and codeine. There was considerable haemorrhage from the bowel. After one month subtotal colectomy was performed and an ileostomy made. The whole colon was found to be severely inflamed and ulcerated. At the time of operation the serum sodium level was 130 , potassium $5 \cdot 8$, and chloride $93 \mathrm{mEq} . / 1$. On the fourteenth post-operative day the ileostomy became completely obstructed. At laparotomy the same day a large abscess cavity in the left loin and a small one in the suprapubic region were drained. The ileostomy acted at once. At the time of this operation the serum sodium level was 133 , potassium $2 \cdot 7$, and chloride $91 \mathrm{mEq} . / 1$. She was given potassium chloride by mouth, and sodium and potassium chlorides intravenously. The volume of ileostomy fluid fell rapidly and the serum potassium became normal. Ileostomy dejecta were collected for 18 days from the ninth day after the ileostomy was made. This period included the brief episode of obstruction and the laparotomy. The relationship of these episodes and of therapy to the chemistry of the ileostomy fluid and the urine is shown in Figure 12.

CASE 11 A woman aged 49 was admitted to hospital with a five-year history of ulcerative colitis. She was anaemic, febrile, dehydrated, and ill. The abdomen became distended and tympanitic. She was treated with $100 \mathrm{mg}$. cortisone daily but her condition deteriorated. Deep ulcers were present in the colon. One month after admission a subtotal colectomy was performed and an ileostomy made. Pre-operatively the serum sodium level level was 132 , potassium $4 \cdot 7$, and chloride $93 \mathrm{mEq} . / 1$. Ileostomy dejecta were examined for five days, starting on the second post-operative day. On the first, third, and fourth days of the collection period the patient received intravenously 2 litres of $4.3 \%$ glucose in $0.18 \%$ saline and 1 litre of $0.9 \%$ saline, and on the second day 3 litres of $4.3 \%$ glucose in $0.18 \%$ saline. On the fourth postoperative day the serum sodium level was 141 , potassium 4·3, and chloride $99 \mathrm{mEq} . / 1$.

CASE 12 A woman with familial polyposis of the colon was first seen at the age of 43 years. She had had abdominal pain and passed two or three loose, and at times bloody, stools daily for the past year. Two of her seven children were found to have polyposis of the colon. Staged removal of the colon and rectum was performed, the patient finally being left with an ileostomy. Carcinoma had developed at one point in the right colon. Her health remained good and at the age of 51 years, six and a half years after the ileostomy was made, ileostomy dejecta were examined for 18 days while she was an out-patient.

CASE 13 A woman aged 53 had suffered from chronic ulcerative colitis for $\mathbf{2 3}$ days and her colon was so exten- 
sively and severely diseased that a subtotal colectomy was performed and an ileostomy made. Nine months later the sigmoid colon and rectum were removed. Ileostomy dejecta were examined for 20 days, starting nine days before the last operation, and continued until ten days after it. The patient ate an ordinary ward diet during this period except for the first four post-operative days.

CASE 14 A woman aged 30 with a four-year history of ulcerative colitis was admitted to hospital in relapse, and treated successfully with A.C.T.H. and later cortisone. A further relapse occurred seven months later and she became so ill that after a further four months subtotal colectomy was performed and an ileostomy made. The sigmoid and rectum were removed five months after this. She received cortisone on the day before and on the day of the second operation, and prednisone and A.C.T.H. during the four days after the operation. The ileostomy dejecta were examined for 20 days, starting on the third day after this operation.

CASE 15 A 49-year-old woman had suffered from ulcerative colitis since 1934. An ileostomy was made elsewhere in 1941. A subtotal colectomy was performed in 1948. Eight years later the rectum was excised and the patient made an uninterrupted recovery. Ileostomy dejecta were examined for the first 11 days after the first operation. The ileostomy had then been established for 15 years.

CASE 16 A 58-year-old woman suffered from continuous watery diarrhoea from her ileostomy for two months. There was no pain. A subtotal colectomy had been performed two years previously for chronic ulcerative colitis of 13 years' duration. The rectum had been excised one year later. The ileostomy had given no previous trouble. On admission she was vomiting. There was obvious weight loss and she was dehydrated. Her condition deteriorated and the blood pressure became unrecordable. The serum level of sodium was 123 , potassium 8.0 , and chloride $70 \mathrm{mEq} . / 1$. The blood urea was $245 \mathrm{mg} . \%$. She was given intravenous $4.3 \%$ glucose in $0.18 \%$ saline solution, oxytetracycline, and cortisone. The state of shock was rapidly relieved and then it was seen that the abdomen was distended, tympanitic, and tender. After two days the blood urea level was $93 \mathrm{mg} . \%$ and the level of serum sodium was 121 , potassium $3 \cdot 4$, and chloride $87 \mathrm{mEq}$./1. Ileostomy dejecta and urine were then examined for the next five days. On each of the first three days of this period the patient received 3 litres of $4.3 \%$ glucose in $0.18 \%$ saline solution. On the fourth day 5 litres were given and on the last day 1 litre. On each of the first two days about $7 \mathrm{~g}$. of potassium chloride was given in the intravenous fluid. On the fourth day the serum level of sodium was 136 , potassium $5 \cdot 9$, and chloride $96 \mathrm{mEq} . / 1$. The blood urea was $47 \mathrm{mg}$. \%. The ileum was found to be obstructed by a cord-like band of fibrous tissue.

CASE 17 A man aged 63 was first seen in 1950 with a three years' history of abdominal pain and intermittent diarrhoea. A hard mass in the right iliac fossa proved on laparotomy to be the inflamed terminal ileum, caecum, and ascending colon. These were removed and a side-to- side ileo-colic anastomosis performed. Histological examination revealed chronic ulcerative colitis. Two years later diarrhoea recurred and he bled profusely from the bowel. His general condition was poor. An ileostomy was created (March 1952) but was always overactive, discharging 2.5 to 3.01 . of dejecta daily. Food appeared at the stoma within an hour of being eaten. This led several times to dehydration and electrolyte deficiency and continuous administration of opium (and later codeine) was necessary. In July 1953 a left hemicolectomy was performed, the rectum and sigmoid colon being left. In March 1956 a partial gastrectomy (Polya) was carried out for an intractably painful bleeding chronic duodenal ulcer. A year later he was found to have steatorrhoea (average faecal fat over 6 days, $36.6 \mathrm{~g}$.) and hypochromic anaemia (haemoglobin $7.9 \mathrm{~g}$. \%). The ileostomy needed refashioning twice (in 1952 and 1954). He has suffered from periodic small bowel colic with reduction or cessation of stomal flow. This is usually relieved by an intramuscular injection of pethidine (100 mg.) given by his doctor. In April 1959 the ileostomy dejecta were examined for 11 days. During this period the daily faecal fat was $35.8 \mathrm{~g}$. The patient was at home and receiving daily $45 \mathrm{mg}$. propantheline bromide and 36 minims tinct. opii during the study.

CASE 18 This was the same patient as case 4, re-admitted to hospital seven months later. The ileostomy had worked normally since it was fashioned seven months previously and the patient was in good health. Ileostomy dejecta and urine were examined for 22 days, starting on the fourth day after excision of the rectum. After a control period the effect was studied of an increased oral intake of sodium and potassium chloride on sodium and potassium excretion. During the experimental period her serum electrolyte concentrations were within normal limits (Fig. 9).

CASE 19 A woman aged 60 , with a history of chronic ulcerative colitis for $\mathbf{1 4}$ years involving only the left half of the colon, had a left hemicolectomy performed and a transverse colostomy made. Ten months later the rectum and sigmoid colon were removed. The condition spread to the right side and three years after the original operation the rest of the colon was removed and an ileostomy made. Five years later she developed abdominal colic and began to lose large amounts of fluid from the ileostomy. She was admitted to hospital febrile, dehydrated, and hypotensive (blood pressure, supine, $104 / 50 \mathrm{~mm} . \mathrm{Hg}$ ). There was collapse of the lung at the right base, and the abdomen was distended. The serum sodium level was 133 , potassium $6 \cdot 2$, and chloride $95 \mathrm{mEq}$./1. The obstruction was relieved by passing a rubber tube up the ileum and the ileal loss soon returned to normal amounts. However, in spite of appropriate treatment the blood pressure fell to $90 / 70 \mathrm{~mm} . \mathrm{Hg}$ (supine), the serum sodium level being 136, potassium 5.0 , and chloride $100 \mathrm{mEq}$./l. Hydration was clinically adequate but severe postural hypotension developed, the blood pressure falling at times to an unrecordable level on standing. Her serum level of sodium remained normal throughout. With further salt therapy her blood pressure rose to $90 / 62 \mathrm{~mm}$. $\mathrm{Hg}$ (standing). At this time ileostomy 
dejecta and urine were examined for 11 days. On the last five days of this period she was given extra sodium chloride ( $2 \mathrm{~g}$. daily) by mouth and on the last three days 1 to $21.0 .9 \%$ saline intravenously. After this the sodium space was still low, being $209 \mathrm{ml} . / \mathrm{kg}$. (normal 290) and the 24-hour exchangeable sodium was also low, being $32.5 \mathrm{mEq} . / \mathrm{kg}$. (normal 36 to 48 ). Further treatment corrected these deficiencies and the blood pressure rose to normal levels.

\section{SUMMARY}

Previous work on the composition of ileostomy fluid is surveyed.

Case histories are presented of 12 patients with new ileostomies, six patients with established ileostomies, and, for comparison, one patient with a transverse colostomy.

Analytical data are given of 181 specimens of ileostomy dejecta from patients with new ileostomies and of 114 specimens from patients with established ileostomies. The mean daily weight of dejecta was $324.8 \mathrm{~g}$. in 64 specimens from new ileostomies and $465.5 \mathrm{~g}$. in 86 specimens from established ileostomies, complicated cases being excluded. The mean water concentration of dejecta was $90.8 \%(w / w)$ in 57 specimens from uncomplicated new ileostomies and $92.0 \%(\mathrm{w} / \mathrm{w})$ from 51 specimens from uncomplicated established ileostomies. The mean daily sodium loss in the dejecta in uncomplicated cases was $35.8 \mathrm{mEq}$. in 64 specimens from new and $53.0 \mathrm{mEq}$. in 86 specimens from established ileostomies. The mean daily potassium loss for the same patients was $6.1 \mathrm{mEq}$. for new and $5.5 \mathrm{mEq}$. for established ileostomies. The sodium concentration of the dejecta in new and established ileostomies is essentially the same, the mean being $114.9 \mathrm{mEq}$. per $\mathrm{kg}$. dejecta or $126 \mathrm{mEq}$. per litre ileostomy water. The potassium concentration of the dejecta is higher in new (mean $22.3 \mathrm{mEq}$. per litre) than in established (mean $12.0 \mathrm{mEq}$. per litre) ileostomies.

Sodium or potassium chloride, by mouth, result in an increased water and sodium content of the dejecta, with little change in the potassium content.

The weight of dejecta correlates well $(r=+0.65)$ with oral water intake.

In complicated cases, sodium and water loss may be great on occasion. Potassium loss is increased, but to a lesser degree than sodium loss.

Large oral doses of codeine may considerably reduce the loss of water, sodium, and potassium in complicated cases.

The possible causes of the results obtained are discussed.
We are greatly indebted to Mr. W. J. Ferguson and Mr. J. Scholefield, who operated on these patients; to Dr. Q. J. G. Hobson for earlier notes of the last admission of case 16 and for allowing us to study case 11 ; to Dr. R. P. K. Coe for transferring case 2 to our care; to Dr. P. M. McAllen for allowing us to study case 8; to Professor J. McMichael for transferring case 15 to our care; to the nursing staff for their help and cooperation, which enabled the collection of specimens to be made.

\section{REFERENCES}

Abbott, W. E., Levey, S., and Krieger, H. (1957). Ileostomy chemistry. Lancet, 2, 149-150.

Brooke, B. N. (1958). Ileostomy chemistry. Dis. Colon Rect., 1, 3-14.

Cammidge, P. J. (1914). The Faeces of Children and Adults. Wright, Bristol.

Coghill, N. F., Lubran, M., McAllen, P. M., Edwards, F., and Richenberg, C. S. (1956). Sodium and potassium absorption and excretion in patients with ulcerative colitis before and after colectomy. Gastroenterologia (Basel), 86, 724-734.

Crawford, N., and Brooke, B. N. (1957). Ileostomy chemistry. Lancet, 1, 864-867.

- (1958). Ileostomy chemistry. Ibid., 1, 586.

Dick, V. S., Maddock, W. G., and Coller, F. A. (1937). Sodium chloride content of gastro-intestinal secretions. Proc. Soc. exp. Biol. (N.Y.), 37, 318-320.

Fowler, D. I., Cooke, W. T., Brooke, B. N., and Cox, E. V. (1959). Ileostomy and electrolyte excretion. Amer. J. dig. Dis., 4, 710-720.

Karr, W. G., and Abbott, W. O. (1935). Intubation studies of the human small intestine. IV. Chemical characteristics of the intestinal contents in the fasting state and as influenced by the administration of acids, of alkalies and of water. J. clin. Invest., $14,893-900$

Kramer, P., Kearney, M. M., and Ingelfinger, F. J. (1962). The effect of specific foods and water loading on the ileal excreta of ileostomized human subjects. Gastroenterology, 42, 535-546.

Lans, H. S. Stein, I. F.. Jr., and Meyer, K. A. (1952). Diagnosis, treatment and prophylaxis of potassium deficiency in surgical patients; analysis of 404 cases. Surg. Gynec., Obstet. 95, 321-330.

Lockwood, J. S., and Randall, H. T. (1949). The place of electrolyte studies in surgical patients. Bull. N.Y. Acad. Med., 25, 228-243.

Lubran, M., Coghill, N. F., and McAllen, P. M. (1957). Ileostomy chemistry. Lancet, $2,894$.

MacFadyen, D. A., Akre, O. H., Duncan, J., Flesch, F., and Mauser, M. (1954). Electrolyte metabolism in ulcerative colitis patients before and after surgery. Gastroenterology, 27, 544-564.

Maddock, W. G. (1949). Some fundamentals in water and electrolyte balance. Ohio State med. J., 45, 462-475.

Miller, T. G., and Abbott, W. O. (1934). Intestinal intubation; a practical technique. Amer. J. med. Sci., 187, 595-599.

Miller, H., and Wilson, G. M. (1953). The measurement of exchangeable sodium in man using the isotope "Na. Clin. Sci., 12, 97-111.

Moore, F. D., and Ball, M. R. (1952). The Metabolic Response to Surgery. Blackwell, Oxford.

Randall, H. T. (1952). Symposium on basic sciences in surgical practice; water and electrolyte balance in surgery. Surg. Clin. N. Amer., 32, 445-469.

Smiddy, F. G., Gregory, S. D., Smith, I. B., and Goligher, J. C. (1960). Faecal loss of fluid, electrolytes, and nitrogen in colitis before and after ileostomy. Lancet, 1, 14-19.

Welch, C. S., Adams, M., and Wakefield, E. G. (1937). Metabolic studies on chronic ulcerative colitis. J. clin. Invest., 16, 161-168.

-, Masson, J. C., and Wakefield, E. G. (1937). Clinical and laboratory findings after excessive loss of intestinal fluid from the ileum. Surg. Gynec. Obstet., 64, 617-621. 